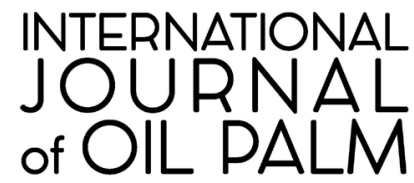

Volume 4, Number 1, 2021

Page 22-30

DOI:10.35876/jop.v4i1.57

ISSN: 2599-3496 print

ISSN: 2614-2376 online

\title{
Epoxidation of Palm Olein as Base Oil for Calcium Complex Bio Grease
}

\author{
Erliza Hambali*, Ni Nyoman Indah Adi Puspita \\ IPB University, Bogor 16680, Indonesia
}

\begin{abstract}
The development of palm oil bio grease aimed to substitute grease made from petroleum with a material that is more environmentally friendly. The enhancement of bio grease characteristics can be performed by chemical synthesis. This research aimed to obtain best mole ratio of palm olein and $\mathrm{H}_{2} \mathrm{O}_{2}$ in the epoxidation process, and to analyze the physical characteristics of the bio grease products. This process used acetic acid and $\mathrm{H}_{2} \mathrm{O}_{2}$ with mole ratio variations of olein and $\mathrm{H}_{2} \mathrm{O}_{2}$ of $1: 3,1: 6$, and $1: 9$. The mole ratio was selected based on the analysis of iodine and oxirane numbers, which was then processed into bio grease with the addition of calcium stearate and calcium acetate. Epoxidized olein with a mole ratio of olein and $\mathrm{H}_{2} \mathrm{O}_{2}$ of 1:9 was selected because it achieved the highest average oxirane number (0.99), the lowest iodine number (33.09), and it was based on ANOVA and LSD tests. The higher the oxirane number, the more epoxide compounds produced. Low iodine number indicated low unsaturation in fatty acids. The peroxy acid used in the epoxidation process reacted with unsaturated compounds, so that the lower iodine number in the epoxidized olein produced more epoxide compounds. Bio grease had a light cream color, density of $0.96 \mathrm{~g} / \mathrm{cm}^{3}$, viscosity of $31,280 \mathrm{mPa} . \mathrm{s}$, unworked penetration of $438(0.1 \mathrm{~mm})$, worked penetration of $443(0.1 \mathrm{~mm})$, dropping point $<26^{\circ} \mathrm{C}$, corrosion resistance of $2 \mathrm{c}$ and NLGI number 00 .
\end{abstract}

Key words: lodine number, NLGI, oxirane number, RBDPO.

\section{INTRODUCTION}

Currently, commercial grease is generally made from petroleum. The substitution of petroleum with vegetable oil as a raw material of lubricants is carried out to produce environmentally friendly grease. One of the vegetable oils that have the potential as a raw material for lubricants is palm oil because its production is quite high. The advantages of bio-lubricants from palm oil compared to petroleum are environmentally friendly, renewable, and biodegradable. The use of grease also includes industrial machinery for food and medicine.

\section{${ }^{*}$ Corresponding author:}

Department of Agroindustrial Engineering, Faculty of Agricultural Engineering and Technology, IPB University, Bogor 16680, Indonesia.

Surfactant and Bioenergy Research Center, IPB University, Bogor 16680, Indonesia.

E-mail: erlizahambali@apps.ipb.ac.id. 
One of the important steps in the production process of grease is the preparation of the base oil. Base oils that can be used are crude palm olein (CPO), palm olein, and its chemical syntheses such as epoxidized olein. The use of formic acid in the epoxidation stage to produce epoxidized olein has the advantage that it takes a very short time due to its highly reactive nature, but has the disadvantage of being quite dangerous because of the risk of a very high temperature increase in the process. Therefore, in this study, acetic acid was used to react with $\mathrm{H}_{2} \mathrm{O}_{2}$ to form peroxyacetic acid in the epoxidation stage.

$$
\begin{aligned}
& \mathrm{HCOOH}+\mathrm{H}_{2} \mathrm{O}_{2} \rightleftarrows \mathrm{HCOOOH}+\mathrm{H}_{2} \mathrm{O} \\
& \mathrm{HCOOOH}+>\mathrm{C}=\mathrm{C} \longrightarrow \stackrel{\mathrm{C}-\mathrm{C}<+\mathrm{HCOOH}}{\longrightarrow}
\end{aligned}
$$

The hydrogen peroxide used in the epoxidation stage must be correct. Lack of the amount of $\mathrm{H}_{2} \mathrm{O}_{2}$ in the reaction can cause the resulting epoxy yield is not optimal. Excess amount of $\mathrm{H}_{2} \mathrm{O}_{2}$ at the equilibrium reaction can cause the decomposition process to produce acetic acid again. The high amount of $\mathrm{H}_{2} \mathrm{O}_{2}$ increases the amount of water in the reaction causing the breakdown of the oxirane ring, so that the resulting epoxy compound is not optimal (Ghozali et al. 2018). Therefore, in this study, the determination of the mole ratio of palm olein and $\mathrm{H}_{2} \mathrm{O}_{2}$ in the epoxidation stage and analysis of the physical properties of the bio grease were conducted.

\section{MATERIALS AND METHODS}

Materials: the main material used was palm olein . Thickener used was a calcium complex made from stearic acid, acetic acid, and calcium hydroxide. Other materials used were distilled water, hydrogen peroxide, hanus reagent, $20 \% \mathrm{KI}$ solution, $0.1 \mathrm{~N}$ sodium thiosulfate solution, starch solution, glacial acetic acid, purple crystal indicator, 0.1 N HBr solution, cyclohexane, chloroform, and copper plates.

\section{Epoxidation}

RBDP olein was stirred and heated in a three neck flask coupled with a condenser to a temperature of $65^{\circ} \mathrm{C}$. The sample was then gradually mixed with acetic acid and $\mathrm{H}_{2} \mathrm{O}_{2}$ until a constant temperature of $70^{\circ} \mathrm{C}$. This epoxidation process used acetic acid and $\mathrm{H}_{2} \mathrm{O}_{2}$ with variations in the mole ratio of olein and $\mathrm{H}_{2} \mathrm{O}_{2}$ as follows: $A$ (1:3), B (1:6), and C (1:9). The epoxidized olein was then separated with a separating funnel and washed with distilled water.

\section{Epoxidized Olein Analysis}

The analysis of the epoxidized olein included the iodine number (Hanus method) and oxirane number (ASTM D1652-97). This study used a completely randomized design (CRD) with 1 factor and 3 levels of testing. The factor used was the mole ratio of epoxidized olein and $\mathrm{H}_{2} \mathrm{O}_{2}$ which consisted of three levels, i.e., 1:3, 1:6, and 1:9. The statistical test used was one way Anova with a $95 \%$ confidence level to determine the effect of the mole ratio using a further test of Least Significant Difference (LSD). This research was conducted with two replications. The general form of the additive CRD linear model is as follows.

$$
Y i j=\mu+T i+\varepsilon i j
$$

Yij is the observed value in the $\mathrm{i}$-th treatment and j-th repetition, $\mu$ is the general middle value, $\mathrm{Ti}$ is the effect of the i-treatment, and $\varepsilon i j$ is the experimental error in the i-th treatment and j-th repetition. 


\section{Production of Bio Grease}

The production process of bio grease was performed in four stages, i.e., saponification, soap dissolving, crystallization and homogenization (Hutagaol 2012). The thickener composition of calcium complex soap was $17 \%$. Commonly used complex calcium soap consisted of calcium 12-hydroxystearate soap which is the saponification result of 12-hydroxystearic acid and calcium hydroxide, and calcium acetate soap which is the saponification result of acetic acid and calcium hydroxide. The mole ratio between calcium acetate and calcium 12-hydroxystearate was 5:1 (Wulandari 2009). However, because 12-hydroxy stearic acid was difficult to obtain in Indonesia, in this study it was substituted with stearic acid from palm oil. The amount of base oil used was $90 \%(\mathrm{w} / \mathrm{w})$. The $90 \%$ epoxidized olein was stirred and heated in a three-neck flask. Acetic acid was mixed into the flask at $25^{\circ} \mathrm{C}$ and then heated to $60^{\circ} \mathrm{C}$. Then the solution was mixed with calcium hydroxide. Heating was continued until $80^{\circ} \mathrm{C}$. Then it was mixed with acetic acid and stirring was continued for 1 hour. 10\% epoxidized olein was added, then stirring and heating was stopped. The bio grease was then homogenized using a mixer.

\section{Analysis of Bio Grease Physical Properties}

Analysis of the bio grease physical properties was performed by several tests. The tests included visual observations, measurements of density, viscosity, corrosion resistance, dropping point, and worked and unworked penetration. Based on the results of the penetration test, the National Lubricating Grease Institute (NLGI) number of the bio grease produced was determined.
Density was measured by a densitometer Anton Paar DMA 5000. Densitometer measures density through vibrations. Liquids with different densities will have different vibrations. The sample was injected into the tube, and the density was then measured by vibration. The results were displayed on the monitor screen.

Visual observation was conducted by observing colors and textures. Viscosity measurement was performed using a viscometer NDJ 8S. This viscometer has 4 rotors and 4 different speeds (6 rpm, 12 rpm, 30 rpm, and $60 \mathrm{rpm}$ ), which makes it possible to measure every viscosity value in the test range.

The penetration test was carried out with a calibrated penetrometer. Each sample was tested for penetration under unworked and worked penetration conditions. The penetration number indicates how deeply the penetrometer cone penetrates the tested solid lubricant. A decrease in the penetration rate indicates a more complex and tougher lubricant structure. The penetration test also determines the NLGI Number which can classify grease based on their properties and uses.

The sanded copper rod was dipped in grease until the copper blade was completely submerged. The copper was then put in an oven at $100^{\circ} \mathrm{C}$ for 24 hours. The test results in the form of color changes on the copper were then matched with the ASTM copper strip corrosion standard.

Melting point is the temperature at which a solid lubricant starts to melt. A high melting point or dropping point is expected in the lubricant, so that the lubricant's function does not decrease when the engine temperature increases. The solid lubricant was put and compacted on the lubricant wall using a compacting rod. The thermometer was installed in contact 
with the solid lubricant. The device was then inserted into a silicon heated vessel. The temperature was raised and then recorded when the solid lubricant began to melt.

\section{RESULTS AND DISCUSSION}

\section{Epoxidized Olein}

This stage was carried out to determine the best mole ratio of olein and $\mathrm{H}_{2} \mathrm{O}_{2}$ to produce epoxidized olein. The best epoxidized olein then was used as base oil in the production of complex calcium bio grease. The determination of the epoxidized olein sample was performed based on the analysis results for iodine and oxirane number. The resulting epoxidized olein had a pale yellow color (Figure 1).

\section{Analysis of lodine and Oxirane Num- bers}

The iodine number indicates unsaturation. The iodine number also determines the inverse of the fatty acids concentration that is converted into epoxide compounds in the epoxidation process. Analysis of iodine numbers was performed using the Hanus method. Analysis of the iodine number of epoxidized olein aimed to determine and compare the number of double bonds that are converted to epoxide groups.

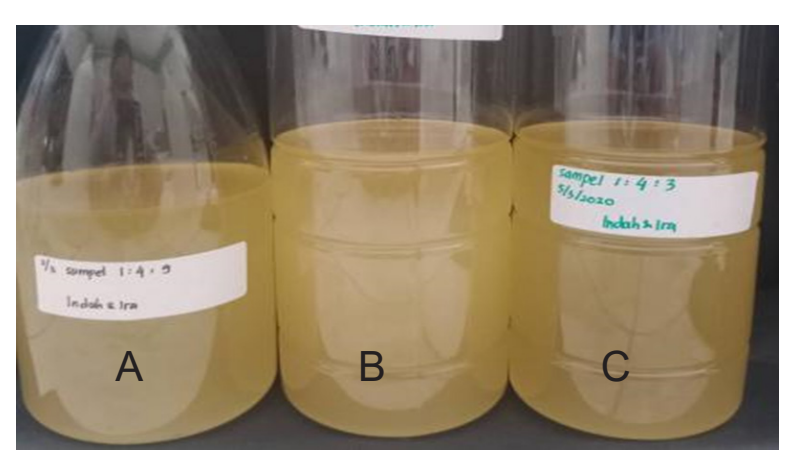

Figure 1 Epoxidized olein with a mole ratio of olein and $\mathrm{H}_{2} \mathrm{O}_{2}$. A 1:9; $\mathrm{B}$ 1:6; C 1:3.
Based on the results of the iodine number analysis for all samples (Figure 2), the iodine number of epoxidized olein was in the range of $33.10-38.23 \mathrm{mg} \mathrm{I} / \mathrm{g}$ of sample. Sample $A$ with a mole ratio of palm olein and $\mathrm{H}_{2} \mathrm{O}_{2}$ of $1: 3$ had an iodine number of $38.23 \mathrm{mg} \mathrm{l}_{2} / \mathrm{g}$ of sample. Sample B with a mole ratio of palm olein and $\mathrm{H}_{2} \mathrm{O}_{2}$ of 1:6 had an iodine number of $34.12 \mathrm{mg} \mathrm{I} / \mathrm{g}$ of sample. Sample $\mathrm{C}$ with a mole ratio of palm olein and $\mathrm{H}_{2} \mathrm{O}_{2}$ had an iodine number of $33.10 \mathrm{mg} \mathrm{I} / \mathrm{g}$ of sample. Meanwhile, palm olein had an iodine number of $55.06 \mathrm{mg} \mathrm{I} / \mathrm{g}$ sample. ANOVA test showed that the effect of the mole ratio of palm olein and $\mathrm{H}_{2} \mathrm{O}_{2}$ was significantly different at the $95 \%$ confidence interval. This shows that the iodine number was influenced by the mole ratio of olein and $\mathrm{H}_{2} \mathrm{O}_{2}$ as an oxidizing agent. The results of the LSD test showed that sample $C$ was not significantly different from sample $B$. Therefore, other parameter test results were needed to determine the best mole ratio of olein and $\mathrm{H}_{2} \mathrm{O}_{2}$.

The decrease in iodine number after epoxidation is caused by the conversion of unsaturated fatty acids into epoxide compounds (Sinaga 2007). The mole ratio of palm olein and $\mathrm{H}_{2} \mathrm{O}_{2}$ which showed the lowest iodine number was

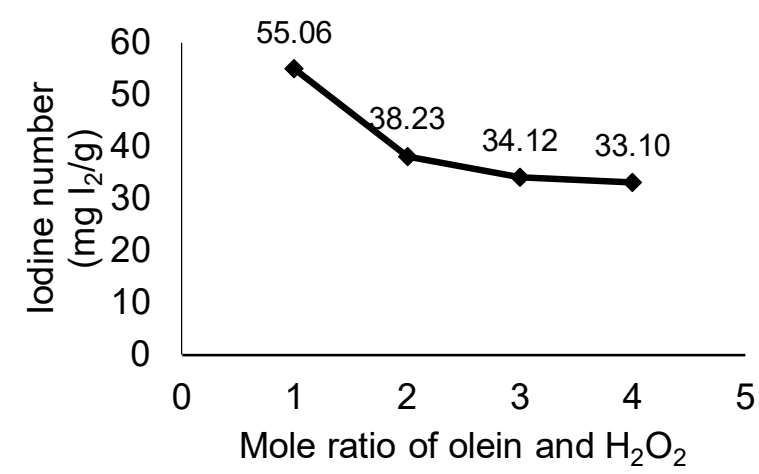

Figure 2 The effect of mole ratio of olein and hydrogen peroxide on the average iodine number. 
sample $\mathrm{C}$. The lower the iodine number, the more epoxy compounds are produced because the oxidation groups in the epoxide compound are formed by oxidizing double bonds (unsaturated) using peroxy acetic acid oxidation (Sinaga 2007).

The epoxy compound is characterized by the presence of oxiraneees. The higher the oxiranee number, the better the epoxy compound produced. The oxirane number shows the amount of epoxide compounds produced (Abdullah 2012). The analysis results of the oxirane number are shown in Figure 3.

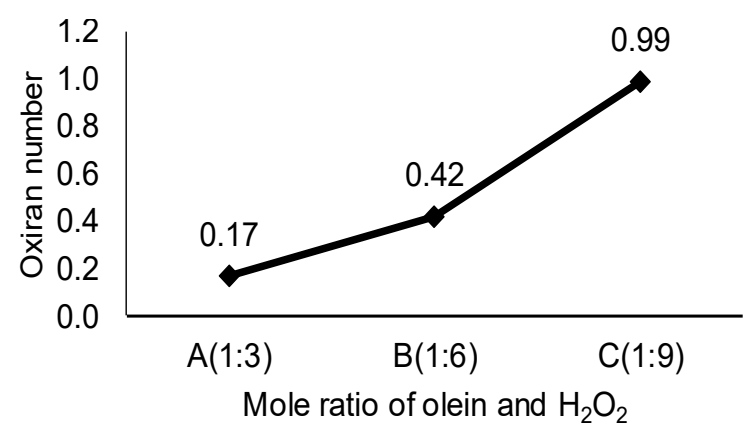

Figure 3 The effect of mole ratio of olein and hydrogen peroxide on the average oxirane number.

Based on the results of the oxirane number of all samples, the oxirane number epoxidized olein was in the range of $0.17-0.99$. Sample A with a mole ratio of palm olein and $\mathrm{H}_{2} \mathrm{O}_{2}$ of $1: 3$ had an oxirane number of 0.17 . Sample B with a mole ratio of palm olein and $\mathrm{H}_{2} \mathrm{O}_{2}$ of $1: 6$ had an oxirane number of 0.42 . Sample $\mathrm{C}$ with a mole ratio of palm olein and $\mathrm{H}_{2} \mathrm{O}_{2}$ had an oxirane number of 0.99 . The mole ratio of palm olein and $\mathrm{H}_{2} \mathrm{O}_{2}$ which achieved the highest oxirane number was sample C. ANOVA test showed that the effect of the mole ratio of palm olein and $\mathrm{H}_{2} \mathrm{O}_{2}$ on the oxirane number was significantly different at the 95\% confidence interval. This shows that the oxirane number was influenced by the mole ratio of olein and
$\mathrm{H}_{2} \mathrm{O}_{2}$ as an oxidizing agent. The LSD test showed that sample $\mathrm{C}$ was significantly different from other samples. Therefore, the epoxidized olein with a mole ratio of olein and $\mathrm{H}_{2} \mathrm{O}_{2}$ 1:9 was the best epoxidized olein. This is because the higher the oxirane number, the more epoxy compounds will be produced (Abdullah 2012). The results of the iodine number are close to the results of the research by Ghozali et al. (2018) that the oxidation number of epoxidized oleic acid is 0.89 to 1.95 .

The best epoxidized olein in this study was sample $C$ with a mole ratio of palm olein and hydrogen peroxide of 1:9. The selection was made based on the results of the quantitative analysis of iodine and oxirane numbers. The synthesis of epoxidized olein aimed to convert the double bonds into epoxide groups. Peroxyacetic acid as an oxidizing agent will react with the double bonds in palm olein in the epoxidation process to produce epoxidized olein. The number of double bonds present in oil is determined by determining the iodine number. The lower the iodine number of the epoxidized olein, the more the double bonds have reacted. The greater the oxirane number, the more epoxy compounds will be produced (Ghozali et al. 2018).

The best epoxidized olein was then used as base oil in the production of complex calcium bio greases. The base oil was mixed with a thickener of the main soap, i.e., calcium stearate and calcium acetate complexing soap with a mole ratio of 1:5. The bio grease calcium complex was then analyzed for its physical properties.

\section{Analysis of Bio Grease Physical Properties}

Analysis of physical properties was performed by several tests. 
The tests included visual observations, measurements of density, viscosity, dropping point, corrosion resistance, consistency (worked and unworked penetration). The NLGI number of the bio grease was determined based on the consistency.

The visual appearance of color and texture was determined by direct observations. The color of the bio grease was light cream with a thick texture (Figure 4). The color of bio grease is influenced by raw materials, additives and thickening agents. The more thickening agent will produce the darker grease color (Hutagaol 2012).

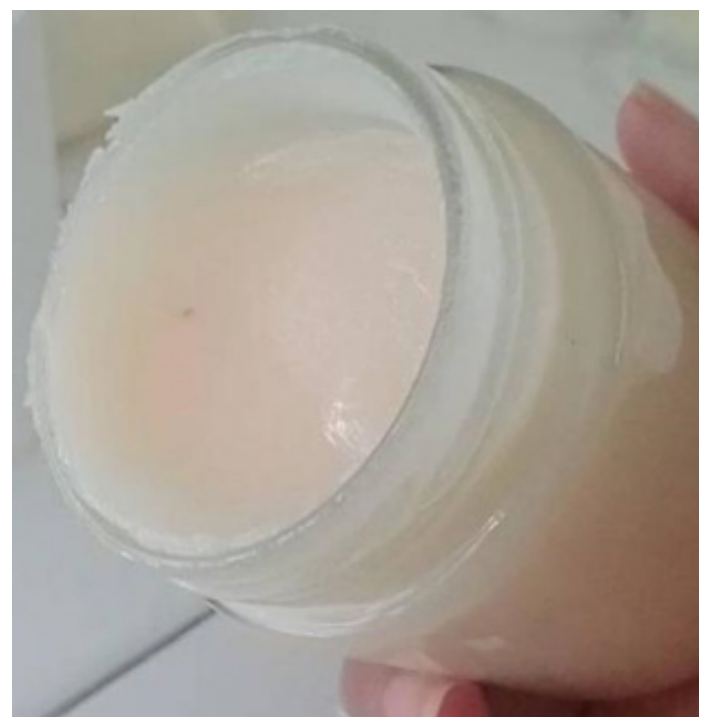

Figure 4 Complex calcium bio grease.

The resulting complex calcium bio grease had a density of $0.961 \mathrm{~g} / \mathrm{cm}^{3}$. The density is relatively the same as commercial lubricants, which ranges from 0.827 to $1.107 \mathrm{~g} / \mathrm{cm}^{3}$ (Lestari and Sukmawati 2019). According to Lestari et al. (2019), density can be affected by the concentration of $\mathrm{Ca}(\mathrm{OH})_{2}$ used. The more the concentration will increase the grease density.

The viscosity of bio grease was measured using a viscometer with a result of $31280 \mathrm{~m}$ Pa.s. Semi-solid lubricants generally have a high viscosity. Viscosity is only used to determine the right grease for a particular application. The viscosity of grease is generally referred to as consistency, and consistency is measured by a penetration test (Lestari et al. 2019).

The consistency of bio grease was measured by penetration consisting of unworked and worked penetration. The penetration rate indicates how deeply the penetrometer cone penetrates the tested solid lubricant. A decrease in the penetration rate indicates a more complex and tougher lubricant structure. Unworked penetration is the penetration rate, which is the original state of grease without any work treatments. For worked penetration, grease was given works (pressed and mixed) using a grease worker equipment of 0,60 , and 1000 steps. The consistency of the grease indicates the penetration levels in which the classification is determined by the NLGI. The greater NLGI number indicates harder grease texture (Abdulbari et al. 2011).

The resulting bio grease has unworked penetration of $438(0.1 \mathrm{~mm})$ and worked penetration of $443(0.1 \mathrm{~mm})$. Based on the penetration results, the bio grease can be classified as NLGI 00 or semi-liquid. This showed that the main soap calcium stearate and complexing soap calcium acetate did not bind oil well. Based on the type of thickener, this grease had properties of smooth, soft, and highly waterproof and was able to support extreme pressure loads and was good for use in temperature conditions $<50{ }^{\circ} \mathrm{C}$. Grease texture was influenced by the type and amount of thickener used. According to Petrucci (1987), the hardness level of calcium is greater than other soaps such as lithium and aluminum, so that the hardness of the grease produced will also be different. The consistency value of the grease depends on the microstructure and 
dimensions of the metal soap or thickener. The higher the concentration of complex soap, the stronger the microstructure, so that the matrix formed is smaller and denser (Adhvaryu 2004).

The melting point is the temperature at which the grease begins to melt. A high melting point or dropping point is expected in the lubricant, so that the lubricant's function does not decrease when the engine temperature increases. The harder grease structure requires higher temperature to melt it. The dropping point of bio grease in this study was $<26^{\circ} \mathrm{C}$. This showed that at temperatures less than $26^{\circ} \mathrm{C}$, a phase change had begun to occur due to the breaking of the bonds between calcium and stearate, as well as calcium with acetate. Therefore, the oil in the matrix was separated.

The method used in the corrosion resistance test was ASTM D 130. The copper plate which was lubricated with grease was put in an oven at $100^{\circ} \mathrm{C}$ for 24 hours. The color of the coated copper plate was then compared with the ASTM standard color of copper corrosion. Corrosion resistance testing was performed to determine the tendency of corrosivity of grease lubricants under certain conditions. The copper plates lubricated with bio grease from this research had the color group of $2 \mathrm{c}$ (multicolour lavender). The occurrence of corrosion indicates that oxidation has occurred. The corrosion process is caused by chemical processes and electro chemical processes (Yanto et al. 2009). Grease with a calcium soap thickener can form a water-in-oil emulsion. Calcium soap can hold a lot of water in a stable emulsion, so the metal surface will be kept wet with oil. Therefore, grease with calcium soap will better protect against corrosion (Wartawan 1998).

\section{CONCLUSIONS}

The best mole ratio of olein and hydrogen peroxide in the epoxidation process was sample $C$ of $1: 9$. Sample $C$ had the highest oxirane number of 0.99 , while the iodine number of sample $C$ was $33.10 \mathrm{mg}$ $\mathrm{I}_{2} / \mathrm{g}$ of sample. The best mole ratio was used for the preparation of complex calcium bio grease with calcium stearate main soap and calcium acetate complexing soap.

Complex calcium bio grease produced with epoxidized olein base oil with a mole ratio of olein and $\mathrm{H}_{2} \mathrm{O}_{2}$ of $1: 9$ had a light cream color, density of $0.96 \mathrm{~g} / \mathrm{cm}^{3}$, viscosity of $31280 \mathrm{~m}$ Pa.s, unworked penetration of $438(0.1 \mathrm{~mm})$, worked penetration of $443(0.1 \mathrm{~mm})$, dropping point $<26^{\circ} \mathrm{C}$, corrosion resistance of $2 \mathrm{c}$, and $\mathrm{NLGI}$ number of 00 . The physical properties of very low dropping points can be improved by the addition of pour point depressant additives or antioxidants.

\section{RECOMMENDATIONS}

It is necessary to conduct further research using Fourier Transform Infrared Spectroscopy analysis to ensure the formation of a three-membered ether ring and to determine the optimal formulation ratio. In addition, it is necessary to conduct research related to the handling of waste byproducts from the epoxidation process, as well as the use of additives to improve the physical properties of bio grease such as pour point depressants, antioxidants, and anti-corrosion. 


\section{REFERENCES}

[ASTM] American Society for Testing Material. 2002. ASTM D217: Standard Test Methods for Cone Penetration of Lubricating Grease. Pennsylvania (US): American Society for Testing Material.

[ASTM] American Society for Testing Material. 2002. ASTM D566: Standard Test Methods for Dropping Point of Lubricating Grease. Pennsylvania (US): American Society for Testing Material.

[ASTM] American Society for Testing Material. 2004. ASTM D130: Standard Test Methods for Corrosiveness to Copper from Petroleum Products by Copper Strip Test. Pennsylvania (US): American Society for Testing Material.

Abdulbari HA, Rosli MY, Abdurrahman HN, Nizam MK. 2011. Lubricating grease from spent bleaching earth and waste cooking oil: tribology properties. Int J Phys Sci. 6(20):4695-4699.

Abdullah S. 2012. Pengaruh waktu reaksi terhadap bilangan hidroksil pada pembentukan polyol dari epoksidasi CPO dan curcas oil. J Konvers. 1(1):15-24.

Adhvaryu A. 2004. Preparation of soybeoil-based greases: Effect of composition and structure on physical properties. J Agric Food Chem. 52:204-214.

Andriana. 2009. Pembuatan gemuk bio foodgrade menggunakan thickener sabun aluminium kompleks. [Skripsi]. Depok (ID): Universitas Indonesia

Campanella A, Baltan'as MA. 2005. Degradation of the oxirane ring of epoxidized vegetable oils with hydrogen peroxide using an ion exchange resin. Catalysis Today. 12: 208-214.

Ghozali M, Meliana Y, Fahmiati S, Triwulandari E, Darmawan A. 2018. Sintesis asam oleat terepoksidasi dengan katalis asam asetat. J Kimia Kemasan. 40(2):63-70.

Hassan MJ, Ani FN, Syahrullail. 2015. Tribological features of refined, bleached and deodourised (RBD) palm olein blends with mineral oil. J Mekan. 38 (1):22-31.

Hutagaol EH. 2012. Pembuatan gemuk bio campuran Li-Ca 12HSA asetat kompleks menggunakan base oil minyak sawit terepoksidasi. [Skripsi]. Depok (ID): Universitas Indonesia.

Lestari S, Irdoni, Nirwana. 2019. Pembuatan grease dari minyak biji karet: mempelajari pengaruh campuran Li$\mathrm{OH}-\mathrm{Ca}(\mathrm{OH})_{2}$ dan rasio base oil. Jom FTEKNIK. 6(2):1-7.

Lestari P, Sukmawati. 2019. Pembuatan sabun logam campuran (Al-Ca) sebagai thickener $\quad \mathrm{pe}$ I u $\mathrm{m}$ a s padat (grease) dari palm fatty acid distillate (PFAD). SEMNASTEK UISU. 2(1):49-52.

Maisaroh, Susetyo IB. 2017. Optimasi pada epoksidasi asam oleat sebagai bahan baku dalam sintesis asam 9,10-Dihidroksi Stearat (DHSA). J Agro-Based Indust. 34(2):96-103.

Pafford, Exxon. 1997. Polyol Ester Composition with Unconverted Hydroxyl Group for Use as Lubricant Base Stock. US Patent 5698502.

Petrucci RH. 1987. Kimia Dasar (Prinsip dan Terapan Modern). Jakarta (ID): Erlangga.

Sharma BK, Adhvaryu A, Perez JM, Erhan SZ. 2006. Biobased grease with improved oxidation performance for industrial application. J Agric Food Chem. 54:7594-7599.

Sinaga M S. 2007. Pengaruh katalis H2SO4 pada reaksi epoksidasi metil ester PFAD (Palm Fatty Acid Distillate). J Teknol Pros. 6(1): 70-74. 
Syawaluddin N. 2009. Pembuatan senyawa epoksi dari metil ester asam lemak sawit destilat menggunakan katalis amberlite. [Thesis]. Medan (ID): Universitas Sumatera Utara.

Wartawan A L. 1998. Pelumas, Otomotif dan Industri. Jakarta (ID): Balai Pustaka.

Wulandari M. 2009. Pembuatan gemuk bio food grade menggunakan thickener sabun kalsium kompleks. [Skripsi]. Depok(ID): Universitas Indonesia.
Yanto T, Naufalin R, Erminawati. 2009. Pengaruh penambahan antikorosi terhadap karakteristik pelumas food grade grease dengan bahan dasar minyak sawit. Makalah Seminar Tahunan MAKSI. Bogor (ID): MAKSI.

Zahir OSD. 2012. Penggunaan asam stearat dan asam oleat sebagai pengganti asam 12-hidroksistearat dalam pembuatan sabun sebagai thickener pada gemuk bio kalsium kompleks. [Skripsi]. Depok (ID): Universitas Indonesia. 